\title{
ANNUAL GENERAL MEETING.
}

\section{February 5th, 1875.}

Robert Etheridar, Esq., F.R.S., F.G.S., \&c., Vice-President, in the Chair.

The following Report was read by the Honorary Secretary :-

REPORT OF THE GENERAL COMMITTEE FOR 1874.

The General Committee have much pleasure in congratulating the Association upon the results of the past year.

A considerable number of new Members have been added to the list, and several of these are already well known throughout the country, by their study and practice of Geological Science. There have been a few losses by death, and, if the number of those who have retired is somewhat more numerous than has been the case of later years, they consisted, with few exceptions, of Members whose interest in the proceedings of the Association was never very ardent.

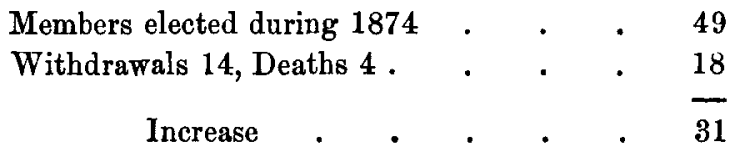

The Census of the Association on the 1st January, 1875, gave the following results:-

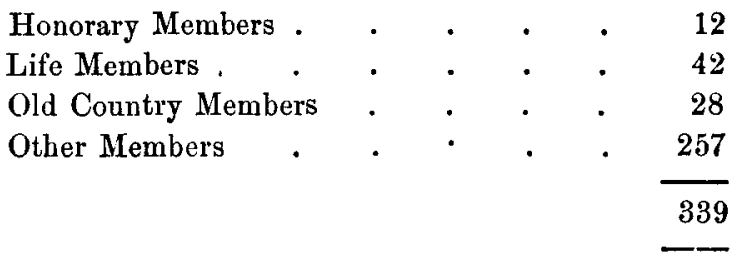

The lamented death of Professor Phillips, reduces the number of Honorary Members to 12. A short notice of the sad occurrence, which deprived the Association of one amongst the most eminent 
of its body, will be found in the forthcoming number of Vol. iv. of the "Proceedings."

The financial position of the Association is very satisfactory, and the large number of Members now contributing has yielded a sum which amply provides for an increased expenditure, the benefits of which are shared by all.. At the same time the Committee venture to suggest the importance of punctuality in the payment of subscriptions, as the smallness of the sum due from each makes it all the more necessary that it should be paid within the current year. A sum of $\mathfrak{E 1 5} 15 \mathrm{~s}$. $0 \mathrm{~d}$, , being the amount of the Life Compositions for the year 1874, has been invested in Consols.

During the year 1874, the Editor has brought ont five numbers of the "Proceedings," completing Vol, iii. Your Committee believe that few other societies give more to their members, by way of publications, in proportion to the very moderate amount at which the subscription is fixed. At the same time your Committee are aware of the great importance of kringing up the publications of Proceedings to a level, in point of time, with the reading of Papers, and the reporting of Excursions, as they feel that much good matter may be withheld from the Association, in consequence of the long time that elapses before an author can hope to see his work in print. It is also equally certain, that the interest in an excursion very often dies away before any record of it appears in the publications of the Association. It is true that some of the larger excursions of the past year have been reported with considerable fulness in the provincial papers, and also, by the kindness of the Editor of the Geological Magazine, have been noticed in its pages, but your Committee hope the time is not far distant when the finances of the Association will permit of an earlier publication of the "Proceedings."

The Papers read at the evening meetings, have been fully equal to the average of previous years ; and as the meetings are generally well attended, there has been a considerable amount of discussion provoked. An interesting Lecture, by your President, on the "Dawn and Development of Life on the Earth," well illustrated by How's Geological Photographs, attracted a large audience. The last meeting of the year was ably occupied by Dr. Carpenter, in showing the important bearing of the doctrine of a Thermal Oceanic Circulation upon Geological Studies. The Pre- 
sident also repeated the practice, so happily commenced by him of delivering an Inaugural Address on the opening of the Session 1874-5.

List of Papers and Lectures read, or delivered, during the year 1874 :-

On the Nature and Origin of Flint and Allied Bodies, by M. HawKIns JoHNSON, F.G.S.

On the Probability of Finding Coal in the Eastern Counties, by JoHN GUNN, F.G.S.

On the Geology of the Neighbourhood of Nottingham, by the Rev. Alexander Irving, B.A., B. Sc., F.G.S.

On the Dawn and Development of Life on the Earth, by the President.

Observations on some Carboniferous Polyzoa, by R. Etheridgr, Junr., F.G.S.

On some Geological Puzzles, by Edward Chartasworth, F.G.S.

On the Lower Greensand and Gault in the Neighbourhood of Folkestone, by F. G. H. PeICE, F.G.S., M.A.I.

On a Collection of Fossils, from the Upper Greensand of Marden, Cambs., by H. Grorge FordhaM, F.G.S.

On Deposits Forming in the British Seas, by G. A. LmBour, F.G.S., F.R.G.S., \&c.

Address at the Opening of the Session 1874-1875, by the Presidernt.

Lecture on the Conditions which determine the Presence or Absence of Animal Life on the Deep Sea Bottom, by Dr, W. B. Carpenter, F.R.S.

During the year 1874 the following Museums and Collections were inspected :-

British Museum-Mineral Collection-Professor MASKmLtwr.

" $\quad$ Fossil Mollusea-Mr. H. Woodward.

Oxford Museum-Professor PHillips.

Collection of Fossils from the Northampton Sand (Inferior Oolite), Lincoln. shire Limestone (Inferior Oolite), and Great Oolite, Mr. Sharp.

Collection of Tertiary and Cretaceous Fossils-Mr. CALEB Evans.

Collection of Lias Fossils-Rev. M. SMrthe.

Collection of Extinct Mammalia-Miss StrickLand.

The Excursions of the Association have been fairly attended by Members and their friends. Subjoined is a list of the Excursions for 1874 , arranged in the order of the formations visited. 


\begin{tabular}{|c|c|c|c|}
\hline FORMATION. & LOCALITIES. & DATEEY. & PRINCIPAL DIRECTORE. \\
\hline 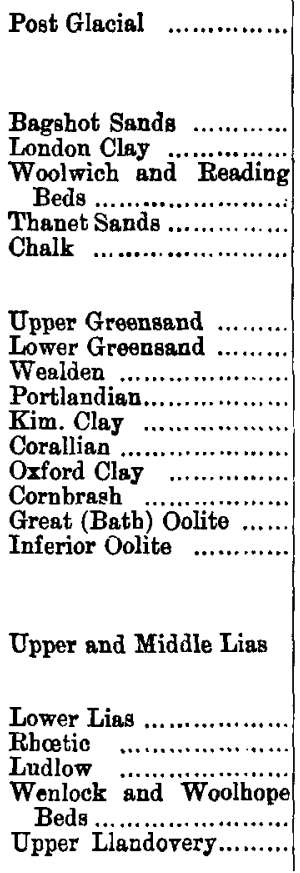 & 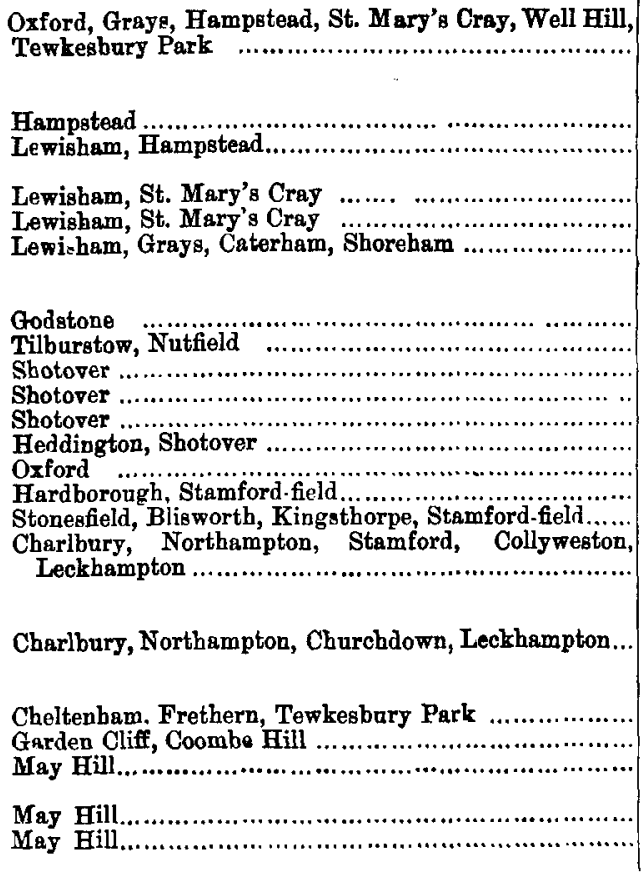 & 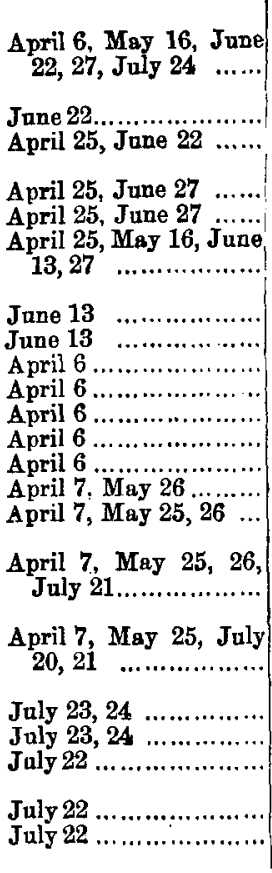 & $\begin{array}{l}\text { Professor Phillips, Mr. Hr. Walker, } \\
\text { Professor Prestwich, Dr. Wright. } \\
\text { Mr. Caleb Evans. } \\
\text { Mr. Whitaker, Mr. Caleb Evans. } \\
\text { Mr. Whitaker, Professor Hughes, } \\
\text { Mr. Whitaker, Professor Hughes. } \\
\text { Professor Morris, Mr. Hy. Walker, } \\
\text { Mr. Lobley, Professor Prestwich. } \\
\text { Mr. Lobley. } \\
\text { Mr. Lobley. } \\
\text { Prolessor Pbillips, Mr Parker. } \\
\text { Professor Phillips, Mr Purker. } \\
\text { Professor Phillips, Mr Parker. } \\
\text { Professor Phillips, Mr Parker. } \\
\text { Professor Phillips, Mr Parker. } \\
\text { Mr. Parker, Mr. Sharp. } \\
\text { Mr. Parker, Mr. Sharp. } \\
\text { Professor Phillips, Mr. Sharp, Dr. } \\
\text { Wright. } \\
\text { Professor Phillips, Mr. Sharp, Dr. } \\
\text { Wright. } \\
\text { Mr. Lucy, Dr. Wright. } \\
\text { Mr. Lucy, Dr. Wright. } \\
\text { Mr. Lobley. } \\
\text { Mr. Lobley. } \\
\text { Mr. Lobley. }\end{array}$ \\
\hline
\end{tabular}


The thanks of the Association for assistance or hospitality rendered on the above mentioned Excursions and Visits are especially due to the authorities of the British Museum; the late Professor Phillips, F.R.S.; Mr. James Parker, F.G.S., Oxford; Mr. W. Whitaker, B.A, F.G.S., Geological Survey; Mr. Samuel Sharp, F.S.A., F.G.S., Dallington Hall, Northampton; Mr. Caleb Evans, F.G.S., Hampstead; Professor Prestwich, F.R.S., Shoreham; Dr. Wright, F.G.S., Cheltenham ; Mr. Lucy, F.G.S., Gloucester; Rev. W. S. Symonds, M.A., F.G.S., Pendock; and Miss Strickland, Apperley Court.

The Library of the Geologists' Association still continues to do good service by circulating standard Geological Works among the Members. The number of books issued during the year shows a slight decrease upon those issued in the preceding Session, but this may be attributed to the fact that one of the meetings was held in a lecture room in the College, where the Library of the Association was consequently inaccessible to Members.

The additions by purchase to the Library have already been notified by circular, and the new Catalogue will show those that have been added through the generosity of Authors.

The Librarian thinks that the Library should, and he hopes shortly will, be used more extensively by Members. He desires to point out that about 75 per cent. of books issued are of the more popular class, and consist chiefly of text-books, and the works of well known Authors; while the remaining 25 per cent. only, are those of the "Proceedings of Societies," and others of a more special character. He thinks it matter for regret that a greater number of the latter kind are not made use of for purposes of research. He would also observe that not more than onefourth of the average number of Members attending the meetings avail themselves of the use of the Library at all.

In accordance with the usual custom, Mr. Henry Woodward, F.R.S., having filled the Presidential Chair during two years, now retires from the post. It is almost unnecessary to point out the great advantages which have accrued to the Association from its connection with a gentleman such as the retiring President. Although largely occupied with the business of an important public department, and snffering still further demands upon his time as Editor of the " Geological Magazine," Mr. Woodward has always contrived to 
find leisure to attend with the utmost exactitude to the affairs of the Association, both in Committee and at the Meetings. He has inaugurated the system, which it is to be hoped may be followed, of delivering an Address at the opening of the Session. On each of these occasions there was a large and attentive audience. Your Committee confidently recommend him for election as an Honorary Member of the Geologists' Association, feeling sure that Members generally will be glad of this opportunity of testifying their regard for one to whom they owe so much. They also recommend Mr. William Whitaker, of the Geological Survey, for election as an Honorary Member.

Your Committee have much pleasure in proposing, as $\mathrm{Mr}$. Woodward's successor, William Carruthers, Esq., F.R.S., F.Z.S., F.G.S., keeper of the Botanical Department in the British Museum, a gentleman who has on several occasions placed his services at the disposal of the Association, and who is well known in the scientific world as the leading authority on Fossil Botany, and also as a most able naturalist and palæontologist. Your Committee have full confidence that Mr. Carruthers will aid in maintaining, as your President, the high character and efficiency of the Association which it has gained for itself during. the terms of office of Mr. Woodward, Professor Morris, Mr. Wiltshire, and other past Presidents of the Society.

Mr. S. R. Pattison, who so kindly undertook about eighteen months ago, at very short notice, the office of Treasurer, finds that the pressure of professional work compels him to tesign his post. This circumstance your Committee much regret.

As his successor your Committee have great pleasure in nominating Mr. F. G. H. Price, whose business abilities and connection with the well-known bankers, Messrs. Child and Co., of No. 1, Temple Bar, point him out as a suitable person to be entrusted with the duties of Treasurer. Your Committee feel sure that this appointment, if confirmed, will be conducive to the financial welfare of the Association.

Your Committee again desire to offer your best thanks to the authorities of University College for the privilege you enjoy of meeting in this beautiful Hall, as well as for the courtesy with which the wishes of the Committee are acceded to. 
For the Year ending December 31st, 1874.

D.)

By Balance, January 18t, 1874

"Admission Fees

, Annual Subscription

, Life Compositions

, Sale of Publications

"Dividend on 2126 16s. 4d.

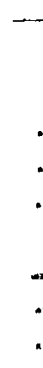

Qr.

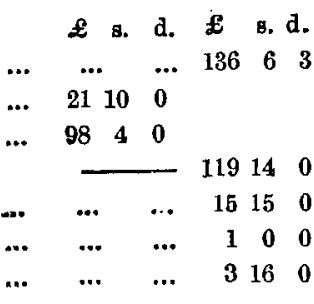

To Printing and illustrating "Proceedings"

"Miscellaneous Printing, including the

$$
\begin{array}{lllllllll}
\text { "Report" } & \ldots & \ldots & \ldots & \ldots & \ldots & 25 & 1 & 3
\end{array}
$$

$\begin{array}{lllllllllll}\text { „, Library } & \ldots & \ldots & \ldots & \ldots & \ldots & \ldots & 7 & 14 & 0\end{array}$

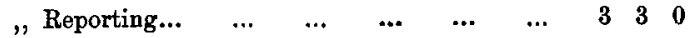

$\begin{array}{llllllll}\text {, Gas and Attendance } & \ldots & \ldots & \ldots & \ldots & 8 & 7 & 6\end{array}$

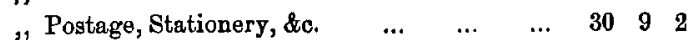

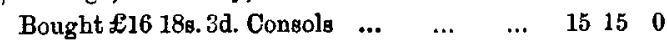

$\begin{array}{llllll}\text { Balance } & \ldots & \ldots & 112 & 16 & 10\end{array}$

$\$ 27611 \quad 3$ s. d.

f276 11 3

We have this day examined the Accounts of the Geologists' Association, and we find that, according to the accounts laid before us, a sum of $£ 487 \mathrm{~s}$. 3d. remained in the bands of the Treasurer on the 31 st December, 1874 , and a sum of $£ 649 \mathrm{~s}$. $7 \mathrm{~d}$. remained in the hands of the late Treasurer at the same date, making together a balance of $£ 11216 \mathrm{~s}$. 10d. due to the Association on the 31 st December, 1874 .

\section{January 19 th, 1875.}

G. STALEY MOSSE, J. SLADE, F.G.S., Auditors.

Beyond the amount of $£ 984 \mathrm{~s}$. received for Annual Subscriptions during the year 1874 , a further sum of $\$ 3110$ s. is due to the Association for Subscriptions remaining unpaid on the 31 st December, 1874 . 
The Report of the General Committee was unanimously adopted as the Annual Report of the Association for $\mathbf{1 8 7 4}$.

Henry Woodward, Esq., F.R.S., F.G.S., F.Z.S., and William Whitaker, Esq., B.A., F.G.S. of Her Majesty's Geological Survey, were duly elected Honorary Members of the Association.

\section{Officers and General Committee,}

Elected at the Annual General Meeting of the Association, held at University College February 5th, 1875 :-

\section{Presidentr.}

William Carruthers, Esq., F.R.S., F.L.S., F.G.S.

\section{Vice-Presidents.}

Robert Etheridge, Eqq., F.R.S.,

F.R.S.E., F.G.S., \&c.

Prof.T. Rupert Jones, F.R.S., F.G.S.

J. Logan Lobley. E\&q., F.G S., F.R.G.S. Heury Woodward, Esq.,F.R.S., F.G.S.

\section{Treasurer.}

F. G. Hilton Price, Esq., F.G.S., F.R.G.S., M.A.I.

HONORARY SECRETARY.

Wilfrid H. Hudleston, Esq., M.A., F.G.S., F.C.S., \&c.

HONORA LY LIBRARIAN.

John A. Coombs, Fsq., F.G.S.

General Committer.

William Carruthers, Esq., F.R.S., F.L.S., F.G.S.

Frank Clarkson, Esq., F.G.S.

John A. Coombs, Esq., F.G.S.

Robert Etheridge,Esq.,F.R.S.,F.R.S.E, F.G.S., \&c.

John Foulerton, Esq., M.J., F.R.S.E.

Gaptain Marshall Hall, F.G.S., F.C.S.

Henry Hicks, Esq., F.G.S., F.R.C.S.

John Hopkinson, Eeq., F.G.S.,F.R.M.S.

Wilfrid H. Hudleston, Esq,, M.A., F.C.S., \&c.

James William Ilott, Eq q.

Matthew Hawkins Johnson, Esq.,F.G.S.
Prof. T. Rupert Jones, F.R.S., F.G.S., \&c.

W. H. Leighton, Esq., F.G.S.

J. Logan Lobley, Esq., F.G.S., F.R.G.S. John East Hunter Peyton, Esq., F.G.S., F.R.A.S.

John S. Phené, Esq., LL.D., F.S.A., F.G.S., \&c.

F. G. Hilton Price, Esq., F.G.S., F.R.G.S.. M.A.I.

F. W. Rudler, Esq., F.G.S., M.A.I.

Jeremiah Slade, Esq., F.G.S.

Henry Woodward, Esq., F.R.S., F.G.S., \&c.

The Thanks of the Association were given to the late President, and to the other Officers of the Association for the past year, for their services, and the Annual General Meeting then terminated. 